\title{
Intracellular Uptake Mechanism of Lutein in Retinal Pigment Epithelial Cells
}

\author{
Yuki Sato, Yu Kondo, Masato Sumi, Yoh Takekuma, Mitsuru Sugawara \\ Faculty of Pharmaceutical Sciences, Hokkaido University, Kita-12-jo, Nishi-6-chome, Kita-ku, Sapporo, Japan.
}

Received, December 6, 2012; Revised, April 10, 2013; Accepted, May 6, 2013; Published, July 26, 2013.

\begin{abstract}
Purpose. Lutein is a carotenoid mainly found in green leafy vegetables and is located in the macula lutea in the human eye. It has received much attention recently due to its preventive effect on age-related macular degeneration, and it has been consumed as a supplement. However, little information about the pharmacokinetic properties of lutein is available. Detailed knowledge of pharmacokinetic properties of lutein is needed for the development of pharmaceutics. In this study, we focused on the macular accumulation of lutein and investigated the uptake mechanism into human retinal pigment epithelial cells. Methods. ARPE-19 cells were used for the study on the accumulation mechanism of lutein. The concentration of lutein was determined using an HPLC system. Involvement of scavenger class B type 1 (SR-B1) in the accumulation of lutein in ARPE-19 cells was suggested from the results of an inhibition study using block lipid transport 1 (BLT-1), a selective inhibitor of SR-B1. To investigate the involvement of SR-B1 in more detail, small interfering RNA (siRNA) was transfected and the mRNA and protein expression levels of SR-B1 were assessed by quantitative real-time reverse transcription polymerase chain reaction and Western blotting, respectively. Results. We confirmed a sufficient siRNA knockdown effect in both mRNA and protein expression levels of SR-B1. We then found that lutein uptake was significantly decreased by siRNA knockdown of SR-B1. Conclusion. The uptake of lutein was significantly decreased by $40 \%$ compared with the control uptake level. This suggested that active transport of lutein into ARPE-19 cells is mainly via SR-B1, given the result that lutein uptake at $4^{\circ} \mathrm{C}$ was about $40 \%$ less that that at $37^{\circ} \mathrm{C}$.
\end{abstract}

This article is open to POST-PUBLICATION REVIEW. Registered readers (see "For Readers") may comment by clicking on ABSTRACT on the issue's contents page.

\section{INTRODUCTION}

Lutein is a major carotenoid that is present in dark green leafy vegetables such as spinach and kale and in various fruits (1). Chemically, lutein differs from other carotenoids. It has two hydroxyl groups, one on each side of the molecule. Thus, it is referred to as a xanthophyll (2). Lutein is a macular pigment that forms yellow spots located in the macula lutea in the human eye (3). Lutein has been thought to have important roles as a blue light filter and powerful oxidant to protect photoreceptors (4). It has been reported that high serum carotenoid level and high dietary intake level of lutein are associated with lower risk of age-related macular degeneration (AMD) (5). AMD is a leading cause of irreversible blindness in the elderly (6). The pathogenesis of AMD is not well understood; however, there is some evidence suggesting that oxidative stress, particularly that caused by reactive oxygen species, contributes to onset of the disease. This is consistent with the hypothesis that lutein has a preventive effect on AMD.
Only two carotenoids, lutein and zeaxanthin, are present in and play an important role in the macula of the human eye. Retinal pigment epithelium (RPE) cells could be an important transfer point for lutein and zeaxanthin uptake by the neural retina from circulating blood. It is therefore meaningful to clarify the retinal transport mechanism of lutein and zeaxanthin. During et al. reported that a xanthophyll (zeaxanthin) was taken up via SR-B1 (scavenger receptor class B type 1) in ARPE-19 cells, a human RPE cell line (7). Dunn et al. reported that ARPE-19 cells express mRNAs of typical RPE markers such as cellular retinaldehyde-binding protein (CRALBP) and RPE-specific protein RPE65 (8). Since the publication of that report, ARPE-19 cells have been frequently used as a model of RPE cells (9-11).

Corresponding Author: Mitsuru Sugawara, Ph. D., Faculty of Pharmaceutical Sciences, Hokkaido University, Kita-12-jo, Nishi-6-chome, Kita-ku, Sapporo, Japan, E-mail: msuga@pharm.hokudai.ac.jp 
On the other hand, the intracellular uptake mechanism of lutein into RPE cells has not been investigated in detail.

Several recent studies using Caco-2 cells as an in vitro model of intestinal absorptive cells have indicated that the intestinal transport of carotenoids is a facilitated process mediated by SR-B1 $(12,13)$. We have also reported that SR-B1 is involved in the absorption of lutein in the intestine (14). The concentration of lutein is slowly increased by a carotenoid-rich diet. Serum concentrations of lutein and zeaxanthin in a high lutein+zeaxanthin diet-intake group were higher than those in a low lutein+zeaxanthin diet-intake group (5). Some studies have shown that macular pigment density is associated with serum concentrations of lutein and zeaxanthin $(15,16)$. It has been calculated that higher levels of the macular pigments range from 0.3 to $1.3 \mathrm{mM}(3,17)$. It has also been reported that the ratio of lutein and zeaxanthin in serum id about $4: 1$ to $5: 1(18,19)$. It is therefore important to clarify the uptake mechanism of lutein into RPE cells in order to clarify the accumulation mechanism of lutein and zeaxanthin in the retina. In this study, we investigated the uptake mechanism of lutein in ARPE-19 cells.

\section{MATERIALS AND METHODS}

\section{Chemicals}

The emulsion formulation of lutein was kindly supplied by JARD Inc. (Tokyo, Japan) and Koyo Mercantile Co., Ltd. (Kyoto, Japan). BLT-1 (Block lipid transport-1), 2-hexy-1-cyclopentanone thiosemicarbazone, was purchased from ChemBridge (San Diego, CA). BLT-1 was dissolved in $100 \%$ DMSO (dimethyl sulfoxide) to form a $10-\mathrm{mM}$ solution as described previously (20). All other reagents were of the highest grade available and used without further purification.

\section{Cell culture}

ARPE-19 cells were obtained from RIKEN (Ibaraki, Japan). The medium used for growth of ARPE-19 cells was Dulbecco's modified Eagle's medium (DMEM)/F12 (Sigma, St. Louis, MO) with 10\% fetal bovine serum and $100 \mathrm{IU}-/ \mathrm{ml}$ penicillin -100 $\mu \mathrm{g} / \mathrm{ml}$ streptomycin (Sigma). Cell culture was performed in an atmosphere of $5 \% \mathrm{CO}_{2} / 95 \%$ air at $37^{\circ} \mathrm{C}$. The cells were given fresh growth medium every 2 days. When the cells had reached confluence after 4-6 days in culture, they were harvested with phosphate buffer saline (PBS; 137 $\mathrm{mM} \mathrm{NaCl}, 2.68 \mathrm{mM} \mathrm{KCl}, 8.10 \mathrm{mM} \mathrm{Na} 2 \mathrm{PO}_{4}, 1.47$

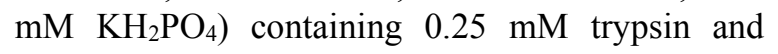

$0.2 \%$ EDTA. Then the cells were re-suspended in the medium and seeded into a new flask.

\section{Uptake study}

ARPE-19 cells were seeded at a density of 1.0-2.0 $\times 10^{5}$ cells $/ \mathrm{cm}^{2}$ on a 12 -well plastic plate (Corning Costar Inc., NY). The cell monolayers were given a fresh medium every 2 days and were used at 4-6 days for the uptake experiments.

The incubation buffer used for the uptake study was HBSS (Hank's balanced salt saline)-HEPES ((pH 7.4) buffer (25 mM D-glucose, $137 \mathrm{mM} \mathrm{NaCl}$, $5.37 \mathrm{mM} \mathrm{KCl}, 0.3 \mathrm{mM} \mathrm{Na}_{2} \mathrm{PO}_{4}, 0.44 \mathrm{mM} \mathrm{KH}_{2} \mathrm{PO}_{4}$, $1.26 \mathrm{mM} \mathrm{CaCl}_{2}, 0.8 \mathrm{mM} \mathrm{MgSO}_{4}$ and $10 \mathrm{mM}$ HEPES, pH adjusted to 7.4 with $1 \mathrm{M}$ Tris). After removal of the medium, $1.0 \mathrm{ml}$ of incubation buffer containing a substrate was added. The monolayers were incubated for the indicated time at 37 or $4^{\circ} \mathrm{C}$. For the inhibition of SR-B1, various concentrations of BLT-1 (final concentration of DMSO: $1 \%(\mathrm{v} / \mathrm{v})$ in HBSS buffer) were used. Each cell monolayer was rapidly washed twice with $1.0 \mathrm{ml}$ ice-cold incubation medium at the end of the incubation period. The cells were then solubilized with $0.5 \mathrm{ml}$ of $0.5 \mathrm{M} \mathrm{NaOH}$ and neutralized with $0.5 \mathrm{ml}$ of 0.5 $\mathrm{M} \mathrm{HCl}$. The samples were kept at $-80^{\circ} \mathrm{C}$ until assay. The concentration of lutein was determined using an HPLC system as described previously (21).

\section{Quantitative real-time PCR}

Total RNA was prepared from ARPE-19 cells using RNAiso (Takara). Single-strand cDNA was made from $2 \mu \mathrm{g}$ total RNA by reverse transcription (RT) using a ReverTra Ace ${ }^{\circledR}$ (TOYOBO). Quantitative real-time PCR was performed using an $\mathrm{Mx} 3005^{\mathrm{TM}}$ Real-time PCR System (STRATAGENE) with SYBR $^{\circledR}$ Premix Ex Taq ${ }^{\mathrm{TM}}$ II (Takara) according to the manufacturer's protocol. PCR was performed using hGAPDH (glyceraldehyde 3-phosphate dehydrogenase)-specific primers through 40 cycles of $94^{\circ} \mathrm{C}$ for $30 \mathrm{sec}, 54.8^{\circ} \mathrm{C}$ for $30 \mathrm{sec}$ and $68^{\circ} \mathrm{C}$ for $30 \mathrm{sec}$ and hSR-B1-specific primers through 40 cycles of $94^{\circ} \mathrm{C}$ for $30 \mathrm{sec}, 60^{\circ} \mathrm{C}$ for $30 \mathrm{sec}$ and $68^{\circ} \mathrm{C}$ for $30 \mathrm{sec}$. The sequences of the specific primers were the same as those described previously (10). The PCR products were normalized to amplified GAPDH, which was the internal reference gene (housekeeping gene), and standard curves were established between the threshold cycles $(\mathrm{Ct})$ and $\log _{10}$ (copy number) as described previously (22).

\section{SR-B1 small interfering RNA (siRNA) and SiRNA transfection}

Specific siRNA (Hs_SCARB1_6763) targeted to 
the hSR-B1 gene and nontargeting siRNA as a negative control (Mission_SIC-001) were purchased from Sigma. Delivery of siRNAs into ARPE-19 cells was performed according to the manufacturer's protocol. Five microliters of hSR-B1 siRNA or nontargeting siRNA $(2 \mu \mathrm{M})$ and $195 \mu 1$ of OPTI-MEM ${ }^{\circledR}$ I Reduced Serum Medium (Gibco, Grand Island, NY) were mixed in 12-well plastic plates and incubated at room temperature for 20 min after addition of $2 \mu \mathrm{l}$ of Lipofectamine ${ }^{\mathrm{TM}}$ RNAiMAX (Invitrogen, Carlsbad, CA). Then 0.8 $\mathrm{ml}$ of suspended ARPE-19 cells $\left(1.5 \times 10^{5}\right.$ cells $)$ in growth medium without antibiotics was added. Following siRNA transfection for $24 \mathrm{~h}$, the medium was replaced with fresh normal growth medium and the the cells were used for analysis.

\section{Western blot analysis}

The cells were scraped and centrifuged at $1,300 \times \mathrm{g}$ for $5 \mathrm{~min}$ at $4^{\circ} \mathrm{C}$. The resulting pellet was suspended in $100 \mu \mathrm{l}$ of lysis buffer $(0.25 \mathrm{mM}$ sucrose, $20 \mathrm{mM}$ HEPES, $\mathrm{pH}$ 7.5). Total cell lysate was obtained by crushing the cells using an ultrasonic homogenizer (IKA) three times for $3 \mathrm{sec}$ each time. The protein concentrations of these samples were determined by the method of Lowry et al. (23). Each sample was denatured at $100^{\circ} \mathrm{C}$ for $3 \mathrm{~min}$ in a loading buffer containing $58.5 \mathrm{mM}$ Tri-HCl, 2\% SDS, 10\% 2-mercaptoethanol, 25\% glycerol and $0.04 \%$ bromophenol blue and separated on $4.5 \%$ stacking and $10 \%$ SDS polyacrylamide gels. Proteins were transferred electrophoretically onto polyvinylidene difluoride membranes (BIO-RAD) at $15 \mathrm{~V}$ for $90 \mathrm{~min}$. The membranes were blocked with PBS containing $0.05 \%$ Tween 20 (T-PBS) and 5\% skim milk powder for $1 \mathrm{~h}$ at room temperature. After being washed with T-PBS, the membranes were incubated with mouse anti- $\alpha$-tubulin and anti-SR-B1 (each diluted 1:500) for $24 \mathrm{~h}$ at room temperature and washed five times with T-PBS for $10 \mathrm{~min}$ each time. The membranes were subsequently incubated for $1 \mathrm{~h}$ at room temperature with horseradish peroxidase-conjugated goat anti-rabbit secondary antibody (Santa Cruz Biochemistry) at a dilution of 1:500 (SR-B1) or 1:1000 ( $\alpha$-tubulin) and washed five times with T-PBS for $10 \mathrm{~min}$ each time. The bands were visualized by ECL Western Blotting detection reagents (GE Healthcare, UK) according to the manufacturer's protocol.

\section{STATISTICAL ANALYSIS}

Student's $t$-test was used to determine the significance of differences between two group means. Statistical significance among means of more than two groups was determined by one-way analysis of variance (ANOVA). Statistical significance was defined as $p<0.05$.

\section{RESULTS}

Temperature-dependent difference in uptake of lutein by ARPE-19 cells

In the first part of study, we investigated the effect of temperature on the uptake of lutein by ARPE-19 cells for up to $60 \mathrm{~min}$ (Fig. 1). The uptake of lutein by ARPE-19 cells was increased up to $60 \mathrm{~min}$ time-dependently. The uptake of lutein for $60 \mathrm{~min}$ and for $30 \mathrm{~min}$ at $37^{\circ} \mathrm{C}$ was significantly increased compared with that at $4^{\circ} \mathrm{C}$. On the other hand, there was no significant difference between uptake levels of lutein at $4^{\circ} \mathrm{C}$ and those at $37^{\circ} \mathrm{C}$ at any other time points. Uptake time was set at 30 min after this study for evaluation of sufficient difference.

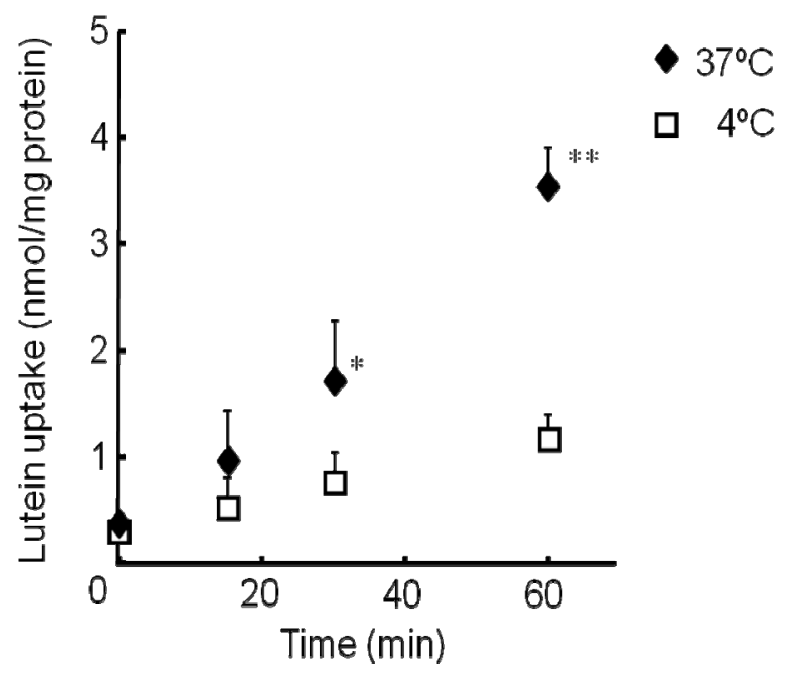

Figure. 1. Temperature-dependence of cellular uptake of lutein by ARPE-19 cells. The uptake of lutein $(35 \mu \mathrm{M})$ was measured at $\mathrm{pH} 7.4$ at $37^{\circ} \mathrm{C}$ (closed symbol) or $4^{\circ} \mathrm{C}$ (open symbol). The concentration of lutein was determined using an HPLC system. Each column represents the mean with S.D. of 6 measurements. *; significantly different from the uptake at $4^{\circ} \mathrm{C}$ at $p<0.05$. **; at $p<0.01$.

\section{Effect of a selective inhibitor of the transporter SR-B1 on uptake of lutein by ARPE-19 cells}

We then investigated the effect of BLT-1, which is a selective inhibitor of SR-B1 (Fig. 2-A). Lutein uptake was almost completely inhibited by BLT-1 at concentrations from 0.01 to $20 \mu \mathrm{M}$ compared with the effect of $0 \mu \mathrm{M}$ of BLT-1 (control). These results suggested that SR-B1 is involved in lutein uptake by ARPE-19 cells. 


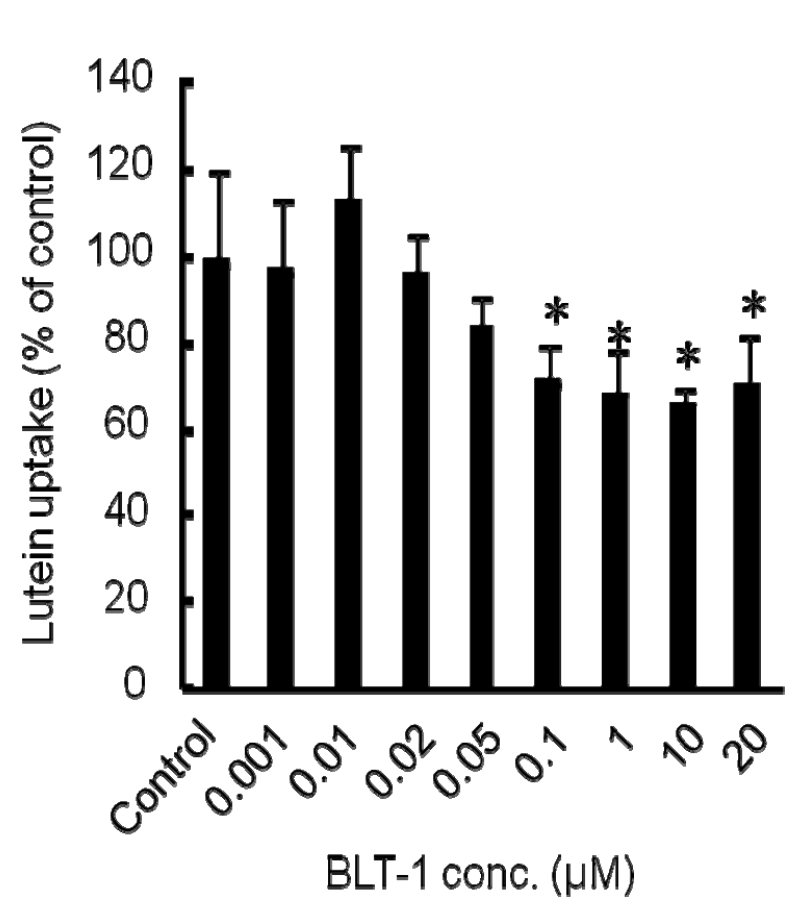

Figure. 2. Inhibitory effect of BLT-1 on uptake of lutein by ARPE-19 cells. The uptake of lutein $(35 \mu \mathrm{M})$ was measured at $\mathrm{pH} 7.4$ at $37^{\circ} \mathrm{C}$ in the presence and absence (control) of BLT-1 (block lipid transport-1) for $30 \mathrm{~min}$. The concentration of lutein was determined using an HPLC system. Each column represents the mean with S.D. of 4 measurements. *; significantly different from the control at $p<0.05$.
Effect of SR-B1 siRNA knockdown in ARPE-19 cells

To clarify whether SR-B1 is associated with lutein uptake in ARPE-19 cells, we investigated the effect of SR-B1 siRNA knockdown in ARPE-19 cells. First, quantitative real-time RT-PCR was performed to quantify SR-B1 mRNA levels at $24 \mathrm{~h}$ after transfection of ARPE-19 cells with siRNA. In this study, an siRNA (\#6763) construct targeting the SR-B1 gene was used.

The siRNA transfection for SR-B1 significantly decreased SR-B1 mRNA level in ARPE-19 cells at $24 \mathrm{~h}$ after transfection (Fig. 3-A). The negative control siRNA (Mission_SIC-001) did not affect SR-B1 mRNA level at $24 \mathrm{~h}$ after transfection compared with that in cells not transfected with siRNA. We also investigated the protein level of knockdown of SR-B1 in ARPE-19 cells at $24 \mathrm{~h}$ after transfection (Fig. 3-B). We confirmed a decreased level of SR-B1 by siRNA transfection in ARPE-19 cells. On the other hand, the negative control did not affect SR-B1 protein level at $24 \mathrm{~h}$ after transfection compared with that in cells not transfected with siRNA. This result correlated well with the mRNA expression level (Fig. 3-B). We also confirmed that the viability of ARPE-19 cells was not decreased at $24 \mathrm{~h}$ after siRNA transfection (supplemental figure). We considered that these conditions were sufficient for knockdown of SR-B1 by siRNA transfection.

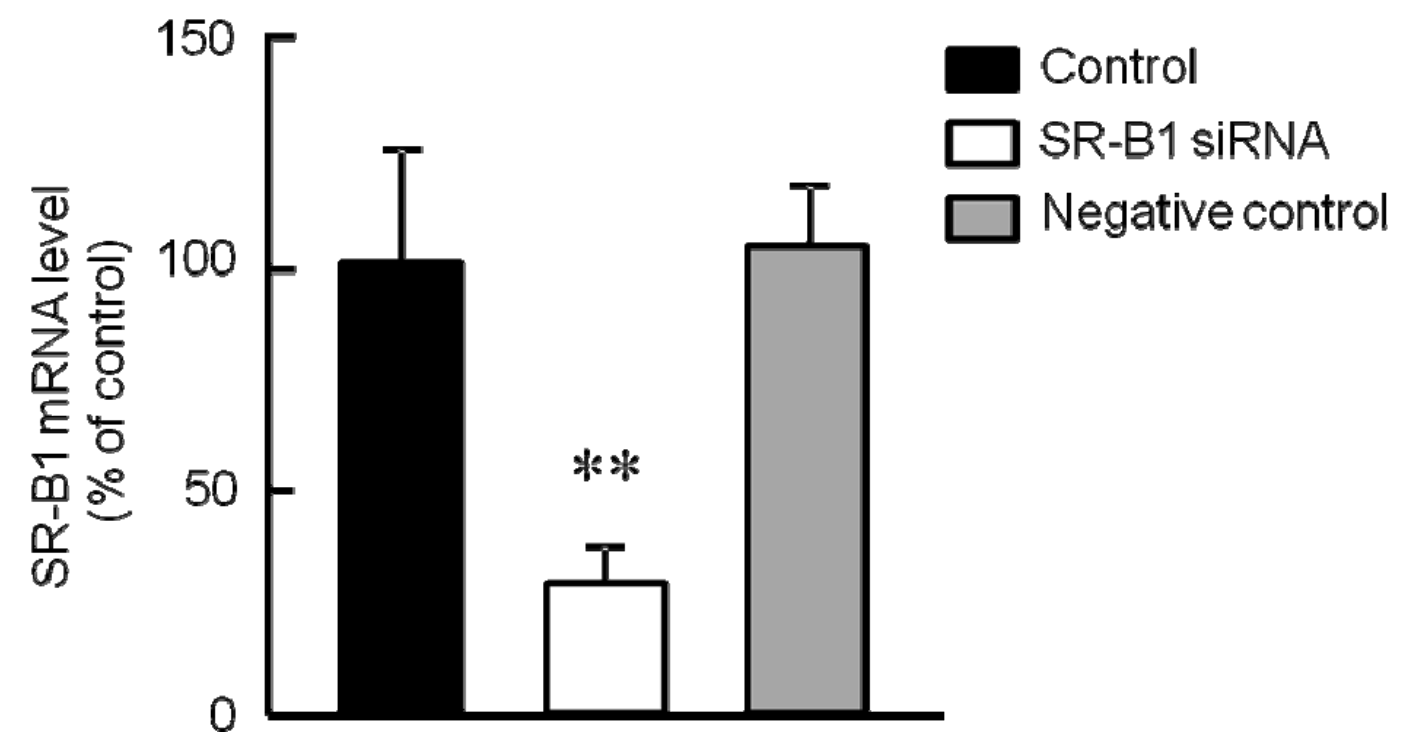

Figure. 3A. siRNA-mediated silencing of SR-B1 mRNA in ARPE-19 cells. ARPE-19 cells were transfected with negative control (nontargeting) or SR-B1 siRNA $(10 \mathrm{nM})$ for $24 \mathrm{~h}$. A double volume was mixed in 6-well plastic plates for analysis of mRNA level as described in Materials and methods. mRNA level after siRNA transfection was assessed by quantitative real-time RT-PCR. Control column represents the mRNA level of cells not transfected with siRNA. Each column represents the mean with S.D. of 3 measurements. **; significantly different from the control at $p<0.01$. 
SR-B1

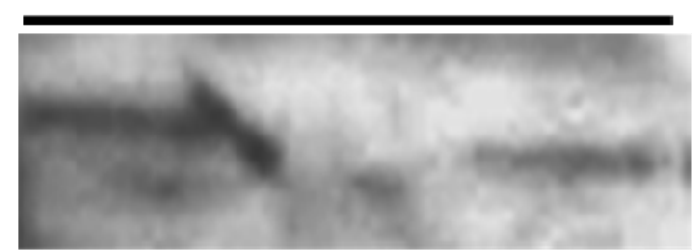

\section{Negative SR-B1} control siRNA siRNA

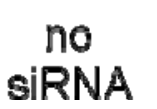

a-tubulin

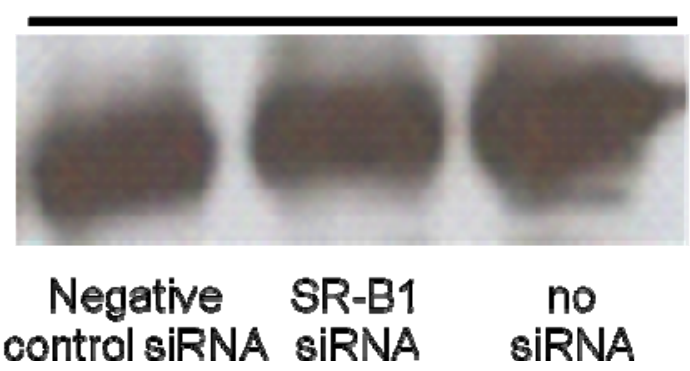

Figure. 3B. siRNA-mediated silencing of SR-B1 protein expression in ARPE-19 cells. ARPE-19 cells were transfected with negative control (nontargeting) or SR-B1 siRNA $(10 \mathrm{nM})$ for $24 \mathrm{~h}$. A double volume was mixed in 6-well plastic plates for analysis of protein expression level as described in Materials and methods. Western blotting (25 $\mu \mathrm{g}$ total protein) was used for analysis of protein expression level after siRNA transfection. Data shown are typical results of 3 independent experiments.

\section{Effect of SR-B1 siRNA on uptake of lutein by} ARPE-19 cells

We then investigated the difference in lutein uptake with siRNA knockdown of SR-B1 in ARPE-19 cells. Uptake of lutein was significantly decreased by $40 \%$ compared with the control uptake level (Fig. 4). These results strongly suggested that SR-B1 is involved in lutein uptake by ARPE-19 cells.

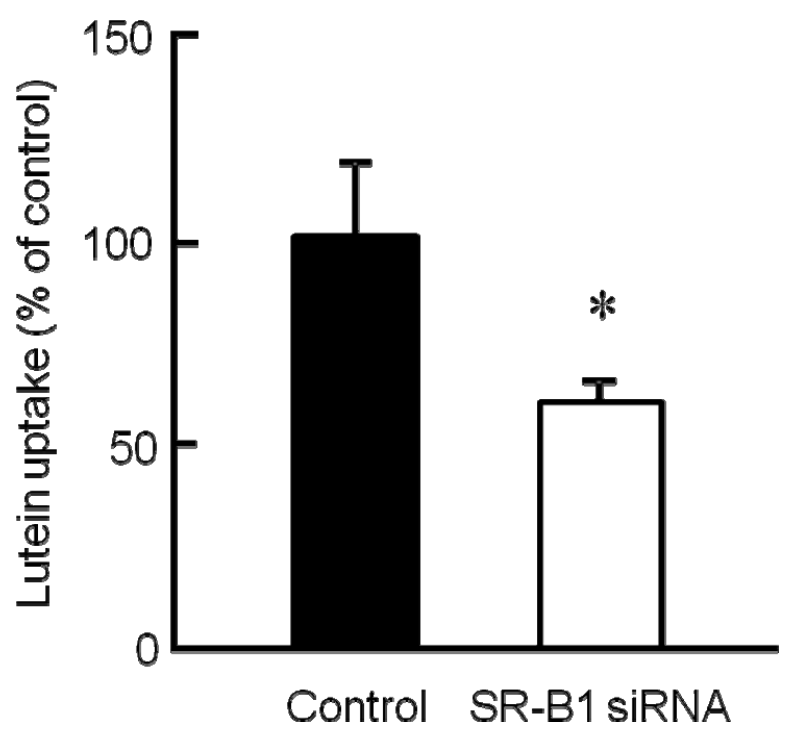

Fig. 4. Inhibitory effect of SR-B1 siRNA knockdown on uptake of lutein by ARPE-19 cells.

ARPE-19 cells were transfected with negative control (nontargeting) or SR-B1 siRNA $(10 \mathrm{nM})$ for $24 \mathrm{~h}$. The uptake of lutein $(35 \mu \mathrm{M})$ was measured at $\mathrm{pH} 7.4$ at $37^{\circ} \mathrm{C}$ for $30 \mathrm{~min}$. The concentration of lutein was determined using an HPLC system. Each column represents the mean with S.D. of 3-4 measurements. *; significantly different from the control at $p<0.05$.

\section{DISCUSSION}

Lutein is a macular pigment that forms yellow spots located in the macula lutea in the human eye and plays a very important role in prevention of AMD. However, the mechanism by which lutein accumulates in the retina has not been fully clarified. We investigated the uptake mechanism of lutein in ARPE-19 cells. Based on some previous reports, we focused on the role of SR-B1 in the intracellular uptake of lutein.

Uptake was studied for $30 \mathrm{~min}$ and the concentration of lutein was under $35 \mu \mathrm{M}$ (data not shown). Lutein uptake in ARPE-19 cells at $37^{\circ} \mathrm{C}$ and that at $4^{\circ} \mathrm{C}$ were different (Fig. 1), suggesting some specific uptake mechanisms in ARPE-19 cells. We previously found by using an intestinal model cell line that SR-B1 and NPC1L1 (Niemann Pick C1-like 1) were involved in the uptake of lutein (14). NPC1L1 is an intestinal cholesterol uptake transporter and is expressed in the apical membrane of the small intestine, particularly in the jejunum, where most of the absorption of lipophilic compounds occurs $(24,25)$. We confirmed by RT-PCR that NPC1L1 in ARPE-19 cells was not expressed at the mRNA level (data not shown). We therefore speculated that SR-B1 is associated with the uptake of lutein by ARPE-19 cells. Lutein uptake by ARPE-19 cells was significantly inhibited by BLT-1, a selective inhibitor of SR-B1 (Fig. 2). At $20 \mu \mathrm{M}$ of BLT-1, lutein uptake was decreased by $25 \%$. To further clarify whether SR-B1 is associated with the intracellular uptake of lutein, we examined the effect of SR-B1 knockdown. First, quantitative real-time RT-PCR was performed to quantify SR-B1 mRNA level at $24 \mathrm{~h}$ after siRNA transfection (Fig. 3-A). Negative 
control siRNA did not affect SR-B1 mRNA level at $24 \mathrm{~h}$ after transfection compared with that in cells not transfected with siRNA. The siRNA for SR-B1 significantly decreased SR-B1 mRNA level in ARPE-19 cells at $24 \mathrm{~h}$ after transfection, and negative control siRNA had no effect on the level in cells (Fig. 3-A). The most effective concentration of siRNA was $10 \mathrm{nM}$ (data not shown). This concentration had little effect on the viability of ARPE-19 cells (supplemental figure). We also investigated whether SR-B1 protein expression correlated with mRNA expression. SR-B1 knockdown by siRNA transfection correlated with a decrease in protein level in ARPE-19 cells at $24 \mathrm{~h}$ after transfection (Fig. 3-B). On the other hand, negative control siRNA did not affect the mRNA level or protein level of SR-B1. The expression of SR-B1 at the mRNA level correlated well with that of SR-B1 at the protein level. We considered these conditions of siRNA knockdown to be sufficient for assaying the contribution of SR-B1 to the uptake in ARPE-19 cells. We then investigated the effect of siRNA knockdown on the intracellular uptake of lutein in ARPE-19 cells. The uptake of lutein was significantly decreased by $40 \%$ compared with the control uptake level (Fig. 4). This suggested that active transport of lutein into ARPE-19 cells is mainly via SR-B1, given the results showing that lutein uptake at $4^{\circ} \mathrm{C}$ was about $40 \%$ less than that at $37^{\circ} \mathrm{C}$ (Fig. 1). We speculate that uptake of lutein into ARPE-19 cells, other than that via SR-B1, is through passive diffusion due to the high lipophilicity of lutein.

Two carotenoids, lutein and zeaxanthin, have protective effects against oxidative stress in the macula. Zeaxanthin is located in the fovea centralis in the macula and lutein is located in outer spots. Bhosale et al. characterized a zeaxanthin-binding protein $\mathrm{Pi}$ isoform of human glutathione S-transferase (GSTP1) (26). Steroidogenic acute regulatory domain 3 (stARD3) was identified as a lutein-binding protein $(27,28)$. stARD was shown to be expressed in mitochondria (29). The human genome has 15 genes encoding stARD proteins that can be divided into six subfamilies (30). stARD proteins bind and transport hydrophobic ligands. Vachali et al. reported that they identified stARD3 (also known as MLN64) as the lutein-binding protein in the human retina (31). MLN64 is a cholesterol-specific stAR-related lipid transfer protein (30). Based on the results of those studies and our study, we speculate that lutein, a high lipiphilic compound like cholesterol, is taken up via SR-B1 into RPE cells and accumulates by binding to this protein in the macula. Further study is needed to clarify the relation between this protein expression and functions of lutein in order to establish some strategies for prevention of AMD.

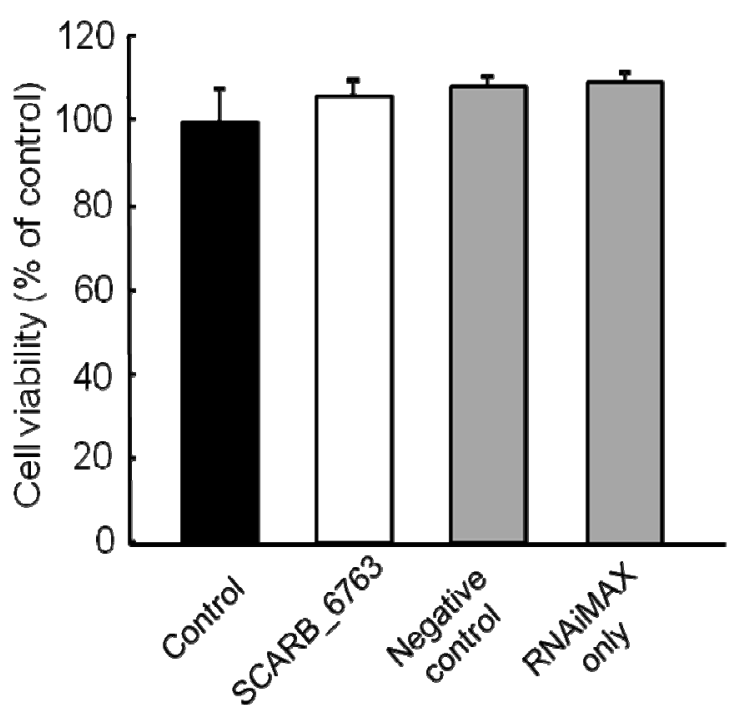

Supplemental Figure. Effect of SR-B1 siRNA knockdown on the viability of ARPE-19 cells. ARPE-19 cells were transfected in 96-well micro plates with negative control (nontargeting) or SR-B1 siRNA $(10 \mathrm{nM})$ for $24 \mathrm{~h}$. Cell viability was measured by WST-8 assay. After transfection, WST- 8 reagent was added to each well, and the cells were incubated at $37^{\circ} \mathrm{C}$ for $3 \mathrm{~h}$. The absorbance of each well was measured at $450 \mathrm{~nm}$ with a microplate reader. The absorbance was expressed as percent of the control (defined as 100\%). Each column represents the mean with S.D. of 3-4 measurements.

\section{CONCLUSION}

In summary, we found that almost all of the intracellular uptake of lutein by active transport into ARPE-19 cells was via SR-B1. There has been some evidence regarding the accumulation mechanism (binding proteins) of the two macular carotenoids. However, it remains unclear how these binding proteins influence the protective effect on oxidative stress in the macula. Further studies are needed to clarify these issues in order to establish more effective and more efficient prophylaxis for AMD.

\section{ACKNOWLEDGEMENT}

We thank JARD Inc. and Koyo Mercantile Co., Ltd. for providing lutein. This work was supported in part by Grants-in-Aid for Regional R\&D Proposal-Based Program from Northern Advancement Center for Science \& Technology of 
Hokkaido and Grants-in-Aid for Young Scientists (B) (Grant number 24790140) from the Japan Society for the Promotion of Science (JSPS).

\section{REFERENCES}

1. Granado F, Olmedilla B, Blanco I, Rojas-Hidalgo E. Major fruit and vegetable contributors to the main serum carotenoids in the Spanish diet. Eur J Clin Nutr, 1996; 50:246-250.

2. Granado F, Olmedilla B, Blanco I. Nutritional and clinical relevance of lutein in human health. $\mathrm{Br} \mathrm{J}$ Nutr, 2003; 90:487-502.

3. Bone RA, Landrum JT, Friedes LM, Gomez CM, Kilburn MD, Menendez E, Vidal I, Wang W. Distribution of lutein and zeaxanthin stereoisomers in the human retina. Exp Eye Res, 1997; 64:211-218.

4. Krinsky NI, Landrum JT, Bone RA. Biologic mechanisms of the protective role of lutein and zeaxanthin in the eye. Annu Rev Nutr, 2003; 23:171-201.

5. Moeller SM, Parekh N, Tinker L, Ritenbaugh C, Blodi B, Wallace RB, Mares JA. Associations between intermediate aged-related macular degeneration and lutein and zeaxanthin in the carotenoids in aged related eye disease study. Arch Ophthalmol, 2006; 124:1151-1162.

6. Fine SL, Berger JW, Maguire MG, Ho AC. Age-related macular degeneration. N Engl J Med, 2000; 342:483-492.

7. During A, Doraiswamy S, Harrison EH. Xanthophylls are preferentially taken up compared with $\beta$-carotene by retinal cells via a SRBI-dependent mechanism. J Lipid Res, 2008; 49:1715-1724.

8. Dunn KC, Aotaki-Keen AE, Putkey FR, Hjelmelan LM. ARPE-19, a human retinal pigment epithelial cell line with differentiated properties. Exp Eye Res, 1996; 62:155-169.

9. Miceli MV, Jazwinski. Nuclear gene expression changes due to mitochondrial dysfunction in ARPE-19 cells: Implications for age-related macular degeneration. Invest Opthalmol Vis Sci, 2005; 46:1765-1773.

10. Lornejad-Schäfer MR, Lambert C, Breithaupt DE, Biesalski HK, Frank J. Solubility, uptake and biocompatibility of lutein and zeaxanthin delivered to cultured human retinal pigment epithelial cells in Tween40 micelles. Eur J Nutr, 2007; 46:79-86.

11. Yamamoto A, Akanuma S, Tachikawa M, Hosoya $\mathrm{K}$. Involvement of LAT1 and LAT2 in the high- and low-affinity transport of L-leucine in human retinal pigment epithelial cells (ARPE-19 cells). J Pharm Res, 2010; 99:2475-2482.

12. Reboul E, Abou L, Mikail C, Ghiringhell O, André M, Portugal H, Jourdheuil-Rahmani D, Amiot MJ, Lairon D, Borel P. Lutein transport by Caco-2 TC-7 cells occurs partly by a facilitated process involving the scavenger receptor class B type 1 (SR-B1). Biochem J, 2005; 387:455-461.

13. During A, Dawson HD, Harrison EH. Carotenoid transport is decreased and expression of the lipid transporters SR-B1, NPC1L1, and ABCA1 is downregulated in Caco-2 cells treated with ezetimibe. J Nutr, 2005; 135:2305-2312.

14. Sato Y, Suzuki R, Kobayashi M, Itagaki S, Hirano T, Noda T, Mizuno S, Sugawara M, Iseki K. Involvement of cholesterol membrane transporter Niemann-Pick C1-Like 1 in the intestinal absorption of lutein. J Pharm Pharmaceut Sci, 2012; 15:256-264.

15. Broekmans W. M., Berendschot T. T., Klöpping-Ketelaars I. A., de Vries A. J., Goldbolm R. A., Tijburg L. B., Kardinaal A. F., van Poppel G. Macular pigment density in relation to serum and adipose tissue concentrations of lutein and serum concentrations of zeaxanthin. Am J Clin Nutr, 2002; 76:595-603.

16. Bone RA, Landrum JT, Guerra LH, Ruiz CA. Lutein and zeaxanthin dietary supplements raise macular pigment density and serum concentrations of these carotenoids in humans. J Nutr, 2003; 133:992-998.

17. Landrum JT, Bone RA, Chen Y, Herrero C, Llerena CM, Twarowska E. Carotenoids in the human retina. Pure Appl Chem, 1999; 71:2237-2244.

18. Curran-Celentano J, Hammond BR Jr, Ciulla TA, Cooper DA, Pratt LM, Danis RB. Relation between dietary intake, serum concentrations, and retinal concentration of lutein and zeaxanthin in adults in a Midwest population. Am J Clin Nutr, 2001; 74:796-802.

19. Olmedilla B, Granado F, Southon S, Wright AJ, Blanco I, Gil-Martinez E, van den Berg H, Corridan, B, Roussel AM, Chopra M, Thuenham DI. Serum concentrations of carotenoids and vitamin A, E, and $\mathrm{C}$ in control subjects from five European countries. Br J Nutr, 2001; 85:227-238.

20. Duong M, Collins HL, Jin W, Zanotti I, Favari E, Rothblat GH. Relative contributions of ABCA1 and SR-BI to cholesterol efflux to serum from fibroblasts and macrophages. Arterioscler Thromb Vasc Biol, 2006; 26:541-547.

21. Sato Y, Kobayashi M, Itagaki S, Hirano T, Noda T, Mizuno S, Sugawara M, Iseki K. Pharmacokinetic properties of lutein emulsion after oral administration to rats and effect of food intake on plasma concentration of lutein. Biopharm Drug Dispos, 2011; 32:151-158.

22. Chisaki I. Kobayashi M, Itagaki S, Hirano T, Iseki K. Liver X receptor regulates expression of MRP2 but not that of MDR1 and BCRP in liver. Biochim Biophys Acta, 2009; 1788:2396-2403.

23. Lowry OH, Rosebrough NJ, Farr AL, Randall RJ. Protein measurement with the folin phenol reagent. J Biol Chem, 1951; 193: 265-275.

24. Altmann SW, Davis HR, Zhu Li-ji, Yao X, Hoos 
LM, Tetloff G, Lyer SP, Maguire M, Golovko A, Zeng M, Wang L, Murgolo N, Graziano MP. Niemann-Pick C1 Like 1protein is critical for intestinal cholesterol absorption. Science, 2004; 303: 1201-1204.

25. Betters JL, Yu L. NPC1L1 and cholesterol transport. FEBS let, 2010; 584:2740-2747.

26. Bhosale P, Larson AJ, Frederick JM, Southwick K, Thulin CD, Bernstein PS. Identification and characterization of a $\mathrm{Pi}$ isoform of glutathione $S$-transferase (GSTP1) as a zeaxanthin-binding protein in the macula of the human eye. J Biol Chem, 2004; 279:49447-49454.

27. Bhosale P, Li B, Sharifzadeh M, Gellermann W, Frederick JM, Tsuchida K, Bernstein PS. Purification and partial characterization of a lutein-binding protein from human retina. Biochemistry, 2009; 48:4798-4807.

28. Li B, Vachali P, Frederick JM, Bernstein PS. Identification of stARD3 as a lutein-binding protein in the macula of the primate retina. Biochemistry, 2011; 50:2541-2549.

29. Douglas M, Barbara J. The role of the steroidogenic acute regulatory protein in steroidogenesis. Steroids, 1997; 62:29-36.

30. Alpy F, Tomasetto C. Give lipids a START: the StAR-related lipid transfer (START) domain in mammals. J Cell Sci, 2005; 118:2791-2801.

31. Vachali P, Li B, Nelson K, Bernstein PS. Surface plasmon resonance (SPR) studies on the interactions of carotenoids and their binding proteins. Arch Biochem Biophys, 2012; 519:32-37. 